\title{
Shelter Spot Seeding Trials with Jack Pine, Black Spruce and White Spruce in Northern Ontario
}

by

\author{
S.W.J. Dominy ${ }^{1}$ and J.E. Wood ${ }^{2}$
}

\begin{abstract}
Seeding trials were established on four different sites in northern Ontario $\left(46^{\circ} 41^{\prime} \mathrm{N}\right.$ to $\left.49^{\circ} 19^{\prime} \mathrm{N}\right)$ in 1979 and 1980. Jack pine (Pinus banksiana Lamb.) was seeded on two medium sand sites, black spruce (Picea mariana [Mill.] B.S.P.) on a sandy clay site, and white spruce ( $P$. glauca [Moench] Voss) on a clay site. Conventional bare spot seeding was compared with spot seeding under Finnish-designed plastic shelters. At least two seeding dates were compared in each trial. Third- and fifth-year stocking and fifth-year height data are presented.
\end{abstract}

Stocking of all three species was increased, regardless of sowing date, when shelters were used. With the exception of June-sown black spruce and one June sowing of jack pine, height growth was not significantly improved through the use of seed shelters. Shelters may prove to be a viable regeneration option only on cooler, exposed sites with little vegetative competition.

Key words: Shelter spot seeding, bare spot seeding, Pinus banksiana Lamb., Picea mariana [Mill.] B.S.P., P. glauca [Moench] Voss.

\section{Résumé}

Des ensemencements expérimentaux ont été effectués à quatre emplacements différents dans le nord de l'Ontario $\left(46^{\circ} 41^{\prime} \mathrm{N}\right.$ à $\left.49^{\circ} 19^{\prime} \mathrm{N}\right)$ en 1979 et 1980. Deux stations sur sable moyen ont été ensemencées en pin gris (Pinus banksiana Lamb.), une station sur argile sableuse, en épinette noire (Picea mariana [Mill.] B.S.P.), et une station sur argile, en épinette blanche ( $P$. glauca [Moench] Voss). La méthode classique d'ensemencement en placeau à découvert a été comparée à la méthode utilisant des abris de plastique de conception finlandaise. Au moins deux dates d'ensemencement ont été comparées dans chaque expérience. Les résultats en ce qui concerne la densité de peuplement à la troisième et à la cinquième années et la hauteur à la cinquième année sont présentés ici.

L'emploi d'un abri a entraîné une augmentation de la densité de peuplement pour les trois espèces à toutes les dates d'ensemencement. Par contre, exception faite de l'épinette noire semée en juin et d'un ensemencement du pin gris en juin, l'emploi d'un abri n'a pas amélioré de façon significative l'accroissement en hauteur. Le semis sous abri pourrait s'avérer une solution adéquate seulement aux stations exposées, plus fraîches, où la concurrence végétale est faible.

Mots clés : Ensemencement en placeau sous abri, ensemencement en placeau à découvert, Pinus banksiana Lamb., Picea mariana [Mill.] B.S.P., P. glauca [Moench] Voss.

\section{Introduction}

This paper reports 5-year results of four northern Ontario trials to compare stocking and growth of jack pine (Pinus banksiana Lamb.) ${ }^{3}$, black spruce (Picea mariana [Mill.] B.S.P.), and white spruce ( $P$. glauca [Moench] Voss) seedlings originating from bare and sheltered seed sown on two or more dates.

Operational seeding was first attempted in Ontario in the late 1940 s and early 1950 s on areas burned by wildfire (Brown

\footnotetext{
1Ontario Ministry of Natural Resources, Box 490, Sault Ste. Marie, Ontario Canada P6A 5M7

${ }^{2}$ Canadian Forestry Service, Great Lakes Forestry Centre, Box 490, Sault Ste. Marie, Ontario, Canada P6A 5 M7.

3Botanical names used in this paper are after Cunningham (1958), Hosie (1979) and Soper and Heimburger (1982).
}

1973). Forest managers envisioned direct seeding as a lowcost regeneration system that was flexible enough for use in treating large and sometimes inaccessible areas on relatively short notice (Benzie 1982). By the early 1960s direct seeding was being widely used in Ontario, and its importance has been steadily increasing to the present. In fact, the total ground and aerial seeding effort has risen from a modest 804 ha in 1962 to 29991 ha in 1982 (Brown 1973, Anon. 1983).

At present, jack pine is the principal species used for seeding in the province. However, there are indications that direct seeding may also be used with other boreal conifers, viz., black spruce and white spruce (cf. Haig 1959, Richardson 1970, Fleming and Groot 1984). Direct seeding can be carried out by spot seeding (applying seeds to small prepared patches), row seeding (applying seeds to prepared rows) or 
broadcast seeding (spreading seeds more or less evenly over a whole area). A reduction in the amount of seed required (Richardson 1974) and greater ability to control seed placement are the main advantages of spot and row seeding over broadcast seeding.

Direct seeding is generally not as successful as planting for reforesting boreal cutovers (Benzie 1982). Excessively high or low surface temperatures and drought are frequently cited as causes of poor seed germination and high seedling mortality (cf. Carmichael 1958, Sims 1970, Fraser 1981). To improve the environmental conditions for seed germination and the early growth of germinates, Finnish researchers in the early 1970 s developed a plastic shelter which is broken down by ultraviolet radiation.

The seed shelter, semi-transparent, cone-shaped and open at both ends (Fig. 1), acts like a miniature greenhouse 4 , effectively increasing the humidity of air and the temperature of both air and soil to levels more favorable to the germination of seeds and the development of seedlings (Lähde and Tuohisaari 1976). The positive results of shelter seeding experiments with conifers in Scandinavia and the desire to increase the reliability of direct seeding in Canada prompted the Canadian Forestry Service to establish several shelter seeding trials in northern Ontario in 1979 and 1980

\section{Study Area}

Four sites representing a range of soil-site conditions in northern Ontario were selected for seeding trials. Two of the sites were seeded with jack pine. Black spruce and white spruce were each seeded on one site.

The first site $\left(46^{\circ} 41^{\prime} \mathrm{N}, 83^{\circ} 26^{\prime} \mathrm{W}\right)$, seeded to jack pine, is located in Parkinson Township within the Algoma Forest Section (L.10) of the Great Lakes-St. Lawrence Forest Region (Rowe 1972). The area consists of a level plain of unstratified, well sorted medium sand with a moderately dry moisture regime (Anon. 1982). A mixed forest of jack pine, white spruce, and trembling aspen (Populus tremuloides Michx.) was clearcut in 1978. The plot area was scarified by a straight tractor blade. Five growing seasons after seeding there was abundant competing vegetation on the site, including trembling aspen, bigleaf aster (Aster macrophyllus L.), red raspberry (Rubus idaeus L. var. strigosus [Michx.] Maxim.), graminoids, and bracken fern (Pteridium aquilinum [L.] Kuhn).

The more northerly jack pine site $\left(48^{\circ} 21^{\prime} \mathrm{N}, 81^{\circ} 20^{\prime} \mathrm{W}\right)$ is an outwash plain of deep, fine to medium sand located in Adams Township within the Missinaibi-Cabonga Forest Section (B.7) of the Boreal Forest Region (Rowe 1972). The experiment was established on a north-facing $5 \%$ slope with a moderately dry to moderately fresh moisture regime (Anon. 1982). The previous forest cover, a predominantly jack pine stand, was clearcut in 1976 and the area was site prepared in 1978 with a CFS Row Scarifier (Smith 1979). Revegetation on the sloping edges of the furrow was light three years after scarification. However, blueberry (Vaccinium spp.) and sweet fern (Comptonia peregrina [L.] Coult.) were abundant on the berm.

The spruce seeding trials $\left(49^{\circ} 19^{\prime} \mathrm{N}, 80^{\circ} 25^{\prime} \mathrm{W}\right)$ are located in Bragg Township within the Northern Clay Section

4Basaraba, D. 1983. Evaluation of the shelter cone seeding method of direct seeding in the east Kootenays. Report prepared for Crestbrook For. Ind. Ltd., Cranbrook, B.C. 7 p. + appendices (unpubl.).

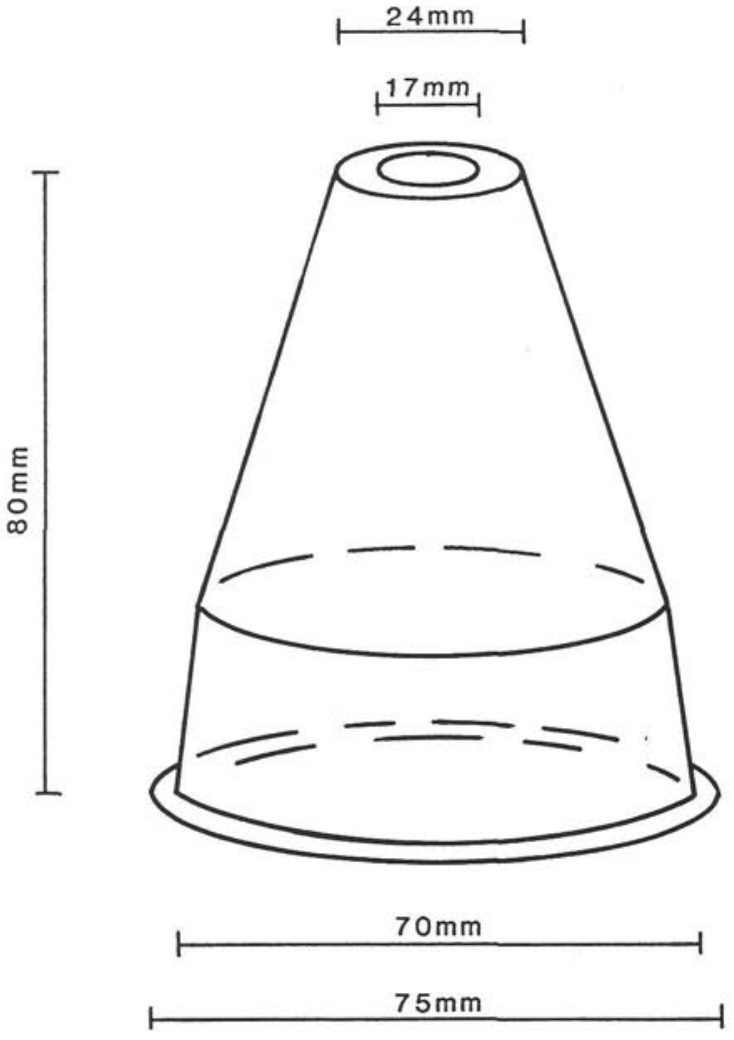

Figure 1. The 'Hakmet' biodegradable semi-transparent plastic seed shelter used in this study.

(B.4) of the Boreal Forest Region (Rowe 1972). The black spruce seeding trial was established on a very moist (Anon. 1982) sandy clay plain of lacustrine origin. A predominantly spruce forest was clearcut in the summer of 1979. The site was prepared with a Rome K/G Clearing Blade (Smith 1979) early in 1980. Five growing seasons later, graminoids and alder (Alnus spp.) were abundant. Red raspberry and willow (Salix spp.) were common on the site.

For the white spruce seeding trial a clay slope of lacustrine origin with a southeasterly aspect was chosen. The site has a fresh moisture regime (Anon. 1982). The plot area is located about $150 \mathrm{~m}$ upslope from the black spruce experiment and was harvested and site prepared in a manner similar to that used for the black spruce site. Trembling aspen and white birch (Betula papyrifera Marsh.) present in the stand prior to harvesting were left standing as residuals. Within one year of seeding there was an abundance of red raspberry, graminoids, trembling aspen, and pin cherry (Prunus pensylvanica L.f.) on the site.

\section{Experimental Methodology}

For convenience, the four seedings will be referred to by township and species. For example, Bragg-Sb represents the black spruce seeding in Bragg Township. Jack pine $=\mathrm{Pj}$ and white spruce $=$ Sw. Parkinson-Pj was established in 1979; the remaining seedings (Adams-Pj, Bragg-Sb, Bragg-Sw) were made in 1980.

Three seeding dates (10 May, 28 May, 25 June) were tested in the 1979 jack pine trial. The 1980 jack pine trial was seeded on 21 June and 17 July. The two spruce trials were seeded on 18 and 19 June and 18 and 19 July. 
For the 1979 plot, seedspots were established on scalped mineral soil microsites. For the 1980 plots, two microsites were selected for each species, these being either sheared Sphagnum or dark peat for black spruce and either duff or mineral soil for white spruce and jack pine. Jack pine in Adams-Pj was seeded on the sloping edges of the scarified furrows so as to avoid the dense vegetative competition present on the berm.

The seeding operation was carried out by: 1) scuffing with the boot to remove loose litter;2) tramping with the boot to flatten the seedspot; and 3) lightly pressing the seeds into the growing medium near the center of the spot. The shelter was held in place over the seeds by firming soil or organic material around the flanged base.

For the 1979 seeding, five jack pine seeds (viability = $87 \%$ ) were placed at each microsite. In the plots established in 1980 , five jack pine seeds (viability $=97 \%$ ), eight black spruce seeds (viability $=97 \%$ ), and ten white spruce seeds (viability = $90 \%$ ) were dropped at each spot. The seeds were not stratified. Reconnaissance surveys conducted after the first and second growing seasons indicated that the germination of summer-seeded white spruce and June-seeded jack pine in Parkinson Township was delayed until the year following seeding. All other seeds germinated in the year of seeding.

Stocking was assessed after the fifth growing season. Total height and current annual height increment of the tallest seedling in each spot were measured after the fifth growing season. Degree of shelter disintegration was also noted in the fifth-year assessment.

Stocking data were analyzed by means of the Pearson Chi-square test on the basis of the relative frequencies of stocked and non-stocked spots. Height data were examined for statistically significant differences by means of one-way analysis of variance. Row means were used as replicates in the analysis of height.

\section{Results and Discussion}

\section{Jack pine}

For each sowing date the sheltered seedspots in Parkinson-Pj and Adams-Pj had significantly better stocking than the bare seedspots (Fig. 2). Lähde and Mutka (1974) have found both air temperature and absolute humidity to be higher inside the shelter than outside. Higher humidity may explain why sheltered seedspots were better stocked than bare seedspots in the later seedings. Also, the ameliorating effect of shelters on the seedling environment encourages rapid seedling development and makes the seedlings more resistant to early frosts and heaving (Lähde 1974 and 1979).

Browsing in the Parkinson-Pj trial, the result of snowshoe hares (Lepus americanus Erxleben), may partially explain why bare spots have lower stocking than sheltered spots (Table 1). Wolff and Lavender (1981) found that plastic shelters protected Douglas-fir (Pseudotsuga menziesii [Mirb.] Franco) seeds and seedlings against seed-eating birds and mammals. Protection from browsing and seed predation is often claimed to be an advantage of sheltering seeds (cf. Lähde 1974 and Lähde and Tuohisaari 1976).

Fifth-year stocking for both sheltered and bare seed spots in Parkinson-Pj and Adams-Pj was higher for the early than for the late sowings (Fig. 2).

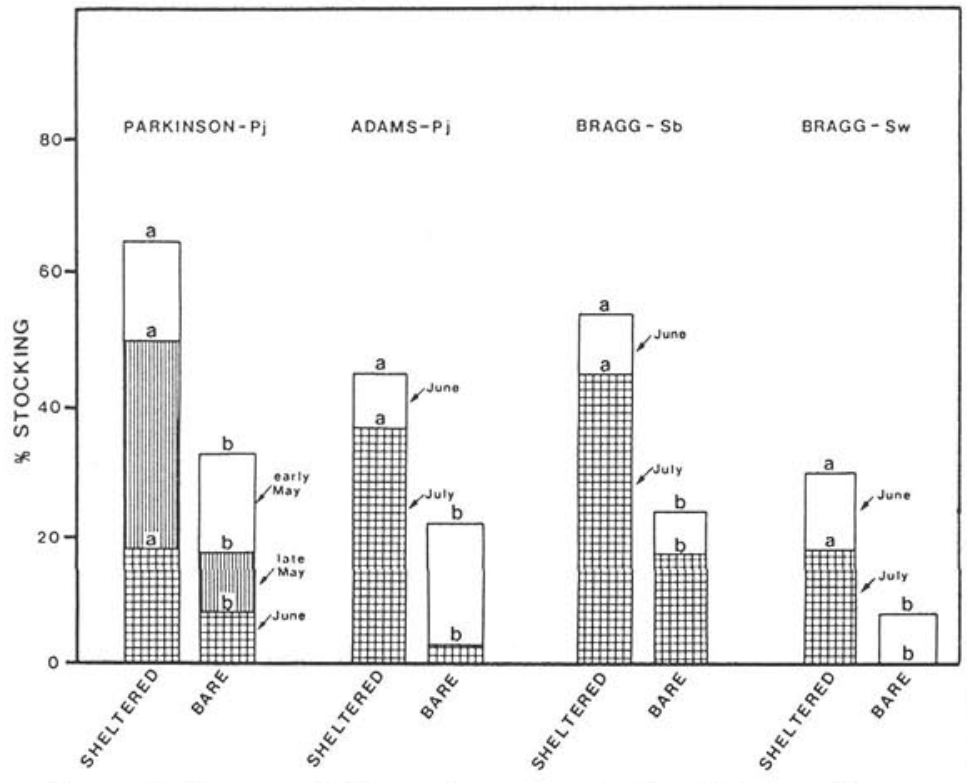

Figure 2. Summary of fifth growing season stocking (\%) by seeding date of shelter-seeded and bare-seeded jack pine (Pj), black spruce (Sb), and white spruce (Sw) on four northern Ontario sites. Differing letters across the same seeding date and within the same experiment indicate a significant difference at the P.05 level.

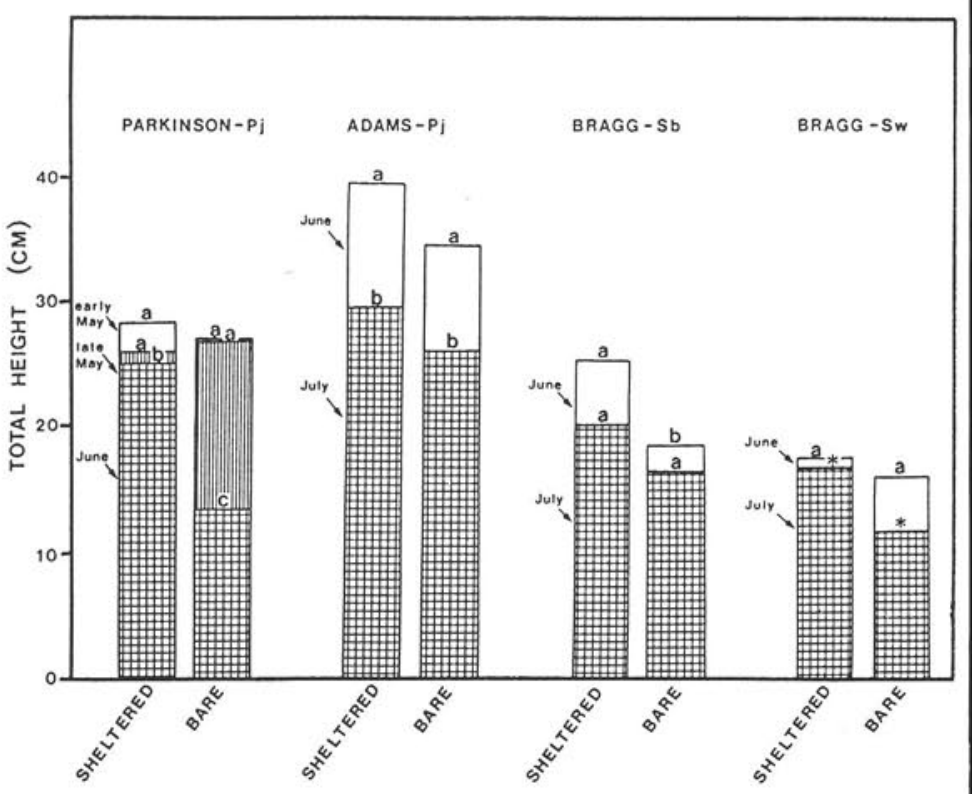

Figure 3. Summary of fifth growing season total height $(\mathrm{cm})$ by seeding date of shelter-seeded and bare-seeded jack pine $(\mathrm{Pj})$, black spruce $(\mathrm{Sb})$, and white spruce $(\mathrm{Sw})$ on four northern Ontario sites. Differing letters across the same seeding date and within the same experiment indicate a significant difference at the P.05 level. *Only one plot stocked.

Only in the last seeding in Parkinson-Pj (25 June) were the seedlings originating in sheltered spots significantly taller (Fig. 3) and faster growing (data not included in report) than those originating in bare seedspots. Similarly, in a study with Scots pine (Pinus sylvestris L.) Lähde and Mutka (1974) concluded that " $[t]$ he favourable effect of the shelter was 
more pronounced for sowings made in July compared to those made in June". In western Finland, it was found that sheltered Scots pine seedlings grew at a faster rate than seedlings started in bare seedspots until the fourth growing season, when they also grew at the same rate (Kinnunen 1982).

\section{Black Spruce}

In both spring and summer seedings in Bragg-Sb the sheltered seedspots had significantly higher stocking than the bare seedspots (Fig. 2). In a mid-June seeding of black spruce near Nipigon, Ontario, Wood and Jeglum (1984) presented five-year data to show that black spruce sheltered seed sown in a clearcut and in first-cut strips on mineral soil also resulted in higher stocking than bare seed sown on the same seedbed types $(61 \%$ and $29 \%$, respectively, in the clearcut and $81 \%$ and $66 \%$, respectively, in the strip cuts). It was interesting to note that the sheltering of seed was more beneficial on the exposed clearcut site than on the protected strip cut site. In experiments comparing sheltered and bare seed of Norway spruce (Picea abies [L.] Karst.) sown in Finland, Lähde (1979) and Lähde and Tuohisaari (1976) observed higher germination and a lower number of nonstocked seedspots with the use of shelters. The generally poor stocking on the Bragg-Sb site is related in part to competition from weeds, viz., graminoids (Fig. 4) and woody shrubs. At the time of seeding, dark peat seedbed was exposed across much of the site. Fleming and Groot (1984) have found dark peat seedbed, while good for seed germination, unsuitable for seedling establishment because of weed competition, flooding, washing, and frost heaving. Planting with large stock would be a more practicable method of regenerating this site type.

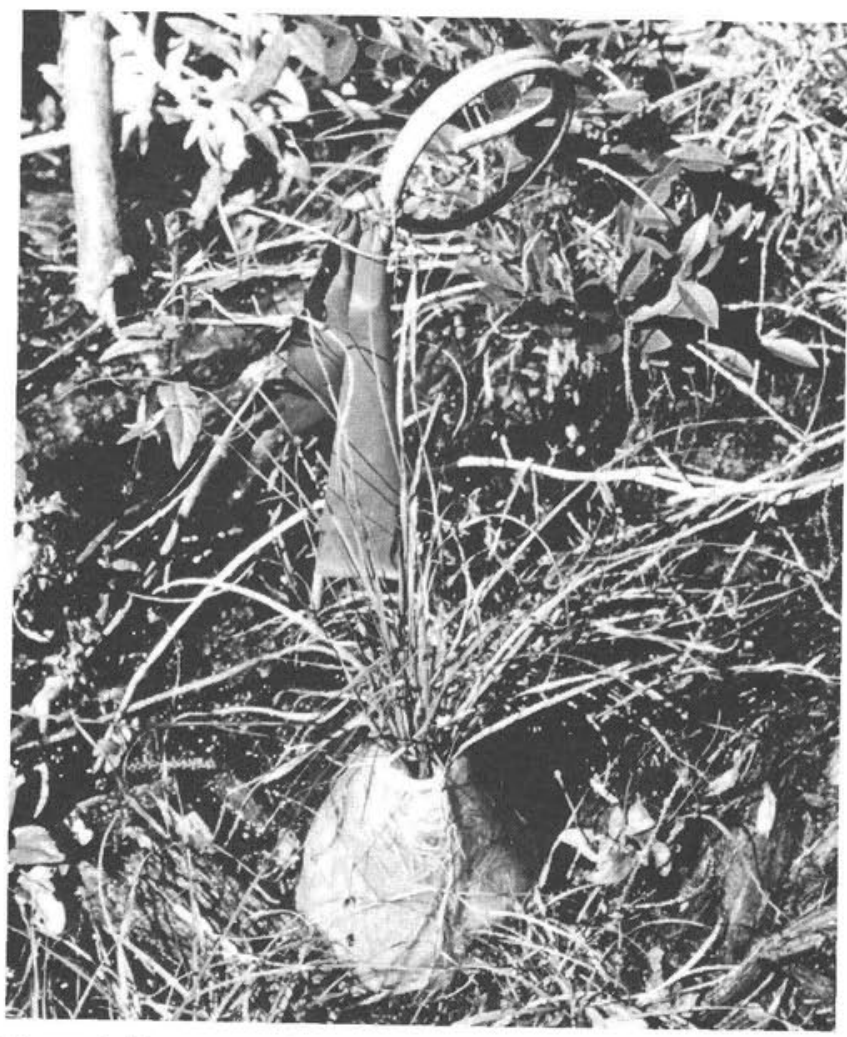

Figure 4. Heavy graminoid competition surrounding and growing beneath the seed shelter. Note how competition has lifted shelter off ground.
The sheltered seedlings started in June were taller (Fig. 3) and faster growing after five growing seasons than seedlings originating from bare seedspots. In contrast with Kinnunen's (1982) observations with Scots pine the benefits of sheltering were still evident on the Bragg-Sb site five years after seeding. Shelters did not appear to improve the total height or height growth of July-sown seedlings.

\section{White Spruce}

Of the three species tested white spruce had the lowest overall stocking (Fig. 2). Seed shelters and early sowing, however, did improve stocking in Bragg-Sw. Generally, growth was not improved by sheltering the seed. The extremely poor stocking of the bare seedspots may be due to the abundance of broad leaf litter (cf. Koroleff 1954), particularly that from trembling aspen regeneration and red raspberry, which formed a continuous and thick mat over the seedspots and either inhibited germination or killed the tiny germinates. The rapid reinvasion of the site by competitive species such as graminoids and red raspberry was also partially responsible for the low stocking.

\section{Shelter Condition (Parkinson, Adams, Bragg)}

Over the range of sites tested, an average of $70 \%$ of the seed shelters either had completely disintegrated or were missing after five years; an average of $18 \%$ were assessed as partially disintegrated (Fig. 5), with the remainder still intact after five years. The Bragg-Sw site had the highest percentage $(29 \%)$ of shelters still intact. The other sites had fewer than $10 \%$ of the shelters intact after five years. In a Finnish study, Raulo and Lähde (1981) found that the degradation of shelters was slowest in the northernmost areas

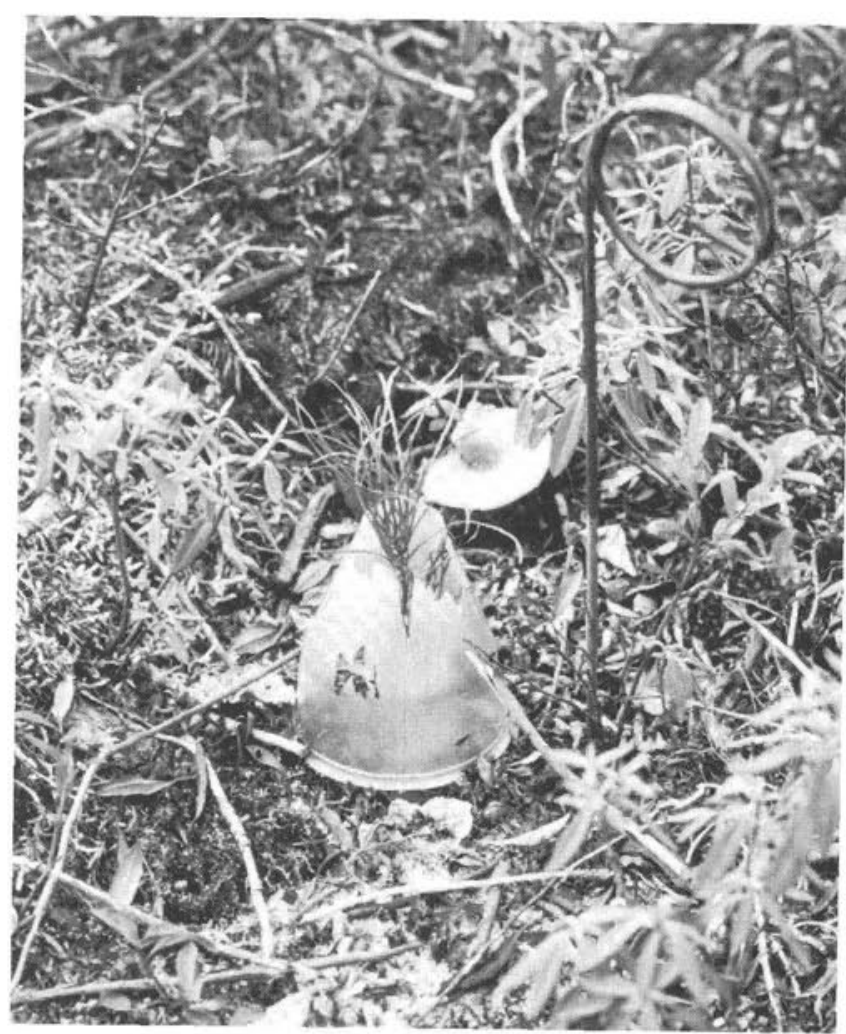

Figure 5. Partially disintegrated seed shelter, after three growing seasons in the field. 
and this suggests that the immediate seedling environment is improved for a longer period in harsher climates. The Bragg sites were the most northerly study areas.

\section{Summary and Conclusions}

The use of seed shelters significantly increased the level of stocking in all trials. Our findings support those of other workers (e.g., Lähde and Tuohisaari 1976, Lähde and Mutka 1974, Wolff and Lavender 1981) who have found that seed shelters improve the environmental conditions for seed germination and germinant development. It follows, therefore, that the use of seed shelters may be beneficial in northern Ontario on exposed sites or on sites on which low temperatures inhibit the germination or development of young germinants. Direct seeding with or without shelters does not appear to be a viable regeneration option on the more productive sites where vegetative competition is likely to hinder survival and growth of germinants.

In general, height growth was not significantly improved through the use of shelters.

Future seed shelter research in northern Ontario should be concentrated on relatively weed-free sites where unsatisfactory stocking is currently attributed to exposure or suboptimal temperatures. Such research should examine environmental factors affecting seed germination and germinant development.

\section{Acknowledgments}

The authors wish to express their appreciation to C.R. Mattice (formerly of the Great Lakes Forestry Centre) for establishing the experiments and to F.W. Curtis of the Great Lakes Forestry Centre for technical assistance. Data collection from 1980 to 1984 was partially funded under the Canada-Ontario Forest Management Subsidiary Agreement.

\section{References}

Anon. 1982. Field manual for describing soils. 2nd ed. Ont. Inst. Pedol., Univ. Guelph, Guelph, Ont. Publ. No. 82-1.

Anon. 1983. Statistics 1983. A statistical supplement to the Annual Report of the Minister of Natural Resources for the year ending March 31, 1983. Ont. Min. Nat. Resour., Toronto, Ont. 123 p.

Benzie, J.W. 1982. Direct seeding upland conifers. p. 291-298 in G.D. Mroz, Comp. Proc. Artificial Regeneration of Conifers in the Upper Great Lakes Region. Mich. Tech. Univ., Houghton, Mich.

Brown, G. 1973. Direct seeding in Ontario. p. 119-124 in J.H. Cayford, Ed. Direct Seeding Symposium. Dep. Environ., Can. For. Serv., Ottawa, Ont. Publ. No. 1339.

Carmichael, A.J. 1958. Determination of the maximum air temperature tolerated by red pine, jack pine, white spruce and black spruce seeds at low relative humidities. For. Chron. 34: 387-392.

Cunningham, G.C. 1958. Forest Flora of Canada. Dep. North. Aff. and Natl. Resour., For. Br., Ottawa, Ont. Bull. 121.144 p.
Fleming, R.L. and A. Groot. 1984. Alternatives for regenerating black spruce clearcuts. p. 2-5 in C.A. Plexman, Ed., Forestry Newsletter. Dep. Environ., Can. For. Serv., Sault Ste. Marie, Ont. Summer 1984

Fraser, J.W. 1981. Experimental seedspotting trials with black spruce on upland cutovers. Dep. Environ., Can. For. Serv., Sault Ste. Marie, Ont. Inf. Rep. O-X-323. 23 p. + appendices.

Haig, R.A. 1959. Result of an experimental seeding in 1920 of white spruce and jack pine in western Manitoba. For. Chron. 35: 7-12.

Hosie, R.C. 1979. Native Trees of Canada. 8th ed. Fitzhenry and Whiteside Ltd., in cooperation with Can. For. Serv. and Can. Gov't Publ. Centre, Ottawa, Ont. 380 p.

Kinnunen, K. 1982. Männyn kylvö karuhkoilla kangasmailla LänsiSuomessa. [English Summary: Scots pine sowing on barren mineral soils in western Finland.] Folia For. 531: 1-24

Koroleff, A. 1954. Leaf litter as a killer. J. For. 52: 178-182.

Lähde, E. 1974. The effect of seed-spot shelters and cold stratification of germination of pine (Pinus silvestris [sic] L.) seed. Folia For. 196: 1-16.

Lähde, E. 1979. Männyn, kuusen ja lehtikuusen suoja- ja avokylvö aurauksen pientareessa ja palteessa. [English Summary: Shelter and open sowing of Scots pine, Norway spruce and Siberian larch on the shoulder and tilt of ploughing.] Commun. Inst. For. Fenn. 97(4): 1-45.

Lähde, E. and K. Mutka. 1974. Kylvösuojan ja raakafosfaattilannoituksen vaikutus männyn siementen itamiseen ja sirkkataimien kehitykseen ojitetulla avosuolla pohjois-suomessa. [English Summary: The effect of sowing shelters and rock phosphate on germination of pine (Pinus silvestris [sic] L.) seeds and development of the germlings on a drained open swamp in Northern Finland.] Commun. Inst. For. Fenn. 83(2): 1 36.

Lähde, E. and O. Tuohisaari. 1976. An ecological study on effects of sowing spot shelters on germination and germling development of Scots pine, Norway spruce and Siberian larch. Commun. Inst. For. Fenn. 88(1): 1-37.

Raulo, J. and E. Lähde. 1981. Rauduskoivun kylvökokeita Lapissa. [English Summary: Sowing experiments with Betula pendula in Finnish Lapland.] Folia For. 461: 1-12.

Richardson, J. 1970. Seedspotting several spruce species on burned land in western Newfoundland. Dep. Fish. For., Can. For. Serv., St. John's, Nfld. Inf. Rep. N-X-48. 19 p.

Richardson, J. 1974. Results of direct seeding research in Newfoundland. Dep. Environ., Can. For. Serv., St. John's, Nfld. Inf. Rep. N-X-114. 33 p.

Rowe, J.S. 1972. Forest Regions of Canada. Dep. Environ., Can. For. Serv., Ottawa, Ont. Publ. 1300. 172 p.

Sims, H.P. 1970. Germination and survival of jack pine on three prepared cutover sites. Dep. Fish. For., Can. For. Serv., Ottawa, Ont. Publ. No. 1283. 19 p.

Smith, C.R. 1979. Silvicultural equipment reference catalogue for northern Ontario. Ont. Min. Nat. Resour., For. Resour. Br., Toronto, Ont.

Soper, J.H. and M.L. Heimburger, 1982. Shrubs of Ontario. R. Ont. Mus., Toronto, Ont. 495 p.

Wolff, S. and D.P. Lavender. 1981. Spot seeding Douglas-fir with small plastic exclosures. p. 313-316 in Proc. Am. Soc. Agric. Eng. Symp. on Eng. Systems for For. Regen. 2-6 March 1981. Raleigh, N.C.

Wood, J.E. and J.K. Jeglum. 1984. Black spruce regeneration trials near Nipigon, Ontario: planting versus seeding, lowlands versus uplands, clearcut versus strip cut. Dep. Environ., Can. For. Serv., Sault Ste. Marie, Ont. Inf. Rep. O-X-361. 19 p. 